\title{
The Structure of the Dictionary Entry of the Educational Linguoculturological Dictionary of Russian Paremias Against the Backdrop of Chinese Language Equivalents: Description Problems
}

\author{
Nadezhda Ye. Yakimenko $\bowtie$, Xueying Qiu \\ St. Petersburg State University, \\ 11, University Embankment, St. Petersburg, Russian Federation, 199034 \\ \yak.nadega@mail.ru
}

\begin{abstract}
The article is devoted to the description of structure and content peculiarities of the dictionary entry of the educational linguoculturological dictionary. The originality of the research concerns the development of the structure and semantics of the dictionary entry of the educational linguoculturological dictionary of paremias representing the concept of BUSINESS in the Russian language. The description takes into account semantic gaps of the culture that the dictionary is focused on. In this article attention is paid to cultural mental attitudes, which are expressed by Russian and Chinese language paremias. Which is why cultural settings were the subject of a linguoculturological description and were offered as one of the main parameters of the educational dictionary. It is the mental attitudes of culture that have become the subject of linguoculturological description and we offer them as one of the main elements of the educational dictionary. The object of the study is the paremias of the two languages that characterize the concepts of business, work, labor, and craft. The aim of the study is to identify and describe the general and national-specific mental attitudes of culture and their representation in the educational linguoculturological dictionary. Russian and Chinese dictionaries of paremias (e.g. the "Big Dictionary of Russian Proverbs", V.M. Mokienko, T.G. Nikitina, E.K. Nikolaeva, collection of proverbs by A.I. Dal, "Big Dictionary of Chinese Proverbs" by Wen Duanzheng) served as the sources of the material. The analysis of bilingual linguoculturological dictionaries is carried out, which helps to identify the basic principles of constructing a dictionary article, and a model of a dictionary article of a linguoculturological educational dictionary aimed at native speakers of the Chinese language is proposed. The creation of the educational linguoculturological dictionaries will help improve the process of intercultural communication.
\end{abstract}

Key words: linguoculturology, lexicography, linguoculturological dictionary, microconcept, dictionary article model, axiology

Article history:

Received: 01.02.2021

Accepted: 15.05.2021

(C) Yakimenko N.E., Qiu Xueying, 2021

This work is licensed under a Creative Commons Attribution 4.0 International License https://creativecommons.org/licenses/by/4.0/ 


\title{
For citation:
}

Yakimenko, N.E. \& Qiu, Xueying. (2021). The Structure of the Dictionary Entry of the Educational Linguoculturological Dictionary of Russian Paremias Against the Backdrop of Chinese Language Equivalents: Description Problems. RUDN Journal of Language Studies, Semiotics and Semantics, 12(3), 905-917. doi: 10.22363/2313-2299-2021-12-3-905-917

\section{Структура словарной статьи учебного лингвокультурологического словаря русских паремий на фоне китайских языковых эквивалентов: проблемы описания}

\author{
Н.Е. Якименко $₫$, Сюэин Цю \\ Санкт-Петербургский государственный университет, \\ 199034, Российская Федераџия, Санкт-Петербург, Университетская набережная, д. 11 \\ \yak.nadega@mail.ru
}

\begin{abstract}
Аннотация. Статья посвящена описанию особенностей структуры и содержания словарной статьи учебного лингвокультурологического словаря. Объектом исследования стали паремии русского и китайского языков, характеризующие понятия ДЕЛО, РАБОТА, ТРУД и РЕМЕСЛО. Цель исследования - выявить и описать общие и национально-специфические ментальные установки культуры и их представление в учебном лингвокультурологическом словаре. Новизна исследования заключается в разработке структуры и семантики словарной статьи учебного лингвокультурологического словаря паремий, представляющих понятие ДЕЛО на русском языке. Описание учитывает семантические пробелы предметной сферы, которой посвящен словарь. В статье рассматриваются ментальные основы двух лингвокультур, которые явились предметом лингвокультурологического описания и были предложены нами в качестве одного из основных параметров словаря образования, и их выражение паремиями русского и китайского языков. Являясь предметом лингвокультурологического описания, ментальные установки культуры стали одним из основных элементов учебного словаря. Источниками сборника послужили русский и китайский словари паремий (например, «Большой словарь русских пословиц» В.М. Мокиенко, Т.Г. Никитиной, Е.К. Николаевой, сборник пословиц А.И. Даля, «Большой словарь китайских пословиц» Вэнь Дуаньчжэна). Проведенный анализ двуязычных лингвокультурологических словарей позволяет выявить основные принципы построения словарной статьи, на основании анализа предложена модель словарной статьи лингвокультурологического учебного словаря, ориентированного на носителей китайского языка. Создание учебных лингвокультурологических словарей поможет улучшить процесс межкультурного общения.
\end{abstract}

Ключевые слова: лингвокультурология, лексикография, лингвокультурологический словарь, микроконцепт, модель словарной статьи, аксиология

\section{История статьи:}

Дата поступления: 01.02.2021

Дата приема в печать: 15.05.2021

\section{Для цитирования:}

Якименко H.Е., Цю Сюэин. Структура словарной статьи учебного лингвокультурологического словаря русских паремий на фоне китайских языковых эквивалентов: проблемы описания // Вестник Российского университета дружбы народов. Серия: Теория языка. Семиотика. Семантика. 2021. Т. 12. № 3. С. 905-917. doi: 10.22363/2313-2299-2021-12-3-905-917 


\section{Introduction}

Linguoculturology is the science of the interaction of language and culture, which intensively develops recently, gradually makes its own conceptual framework, devises different ways of describing linguistic material. RAS academician V.V. Vorobiev gives the following definition of this branch of linguistics: "Linguoculturology is a complex scientific discipline of a synthesizing type that studies the correlation and interaction of culture and language in its functioning and captures this process as a complete structure of units in the unity of linguistic and extra-linguistic content, using systemic methods and focusing on modern priorities and cultural attitudes" [1. P. 37]. The object of linguoculturological study is various kinds of phraseological units (bonuses, periphrases, stable comparisons, phraseological units) [for example, $5 ; 6 ; 14 ; 18$ ].

Today the topic of describing phraseological material in linguoculturological educational dictionary is in the spotlight of academics. One of the methods of representing paremias (as a type of phraseological units) in dictionaries like this is highlighting mental attitudes of a certain culture.

Like any other discipline, linguoculturology does not exist in a vacuum only for satisfying the scientific interest of a few persons. First, it deals with the pressing issues of ordinary people. That is what V.V. Vorobiev highlights in his definition, speaking of "modern priorities and cultural attitudes" [1]. Today, in the world of globalization and unification, there is not enough information about the characteristics in the way various ethnic groups feel and experience. This problem leads to a lot of conflicts and misunderstandings between people. The creation of different kinds of linguoculturological dictionaries targets to solve these issues.

Dictionary is a cultural and historical phenomenon, as Yu.D. Apresyan wrote, this is a snapshot of an ever-renewing and ever-changing language [2. P. 18]. In the other definition, T.A. Demeshkina notes, "dictionaries have great informative feature and serve as a source of theoretical constructions and development of other aspects of analysis. There is also an inverse connection between "scientific development - dictionary", during which the dictionary is a field of the implementation of a particular scientific concept (for example, the theory of motivation, linguistic personalology)" [10. P. 31]. The task of linguoculturological dictionaries, according to the well-known Soviet linguist V.N. Telia's opinion, comes down to fairly comprehensive reflect all kinds of aspects of the certain culture through selected examples of linguistic units [20. P. 5]. In addition to this, she pays attention to such linguoculturological dictionaries characteristic: they represent how the "cultural factor in language and the language factor in a person" is displayed [20. P. 222].

Today linguoculturological dictionaries occupy an intermediate position between linguistic and encyclopedic dictionaries, and "linguoculturography is considered as a modern development stage of linguistic encyclopedic lexicography" [12. P. 43-44]. T.B. Bankova and G.V. Kalitkina presume, "dictionaries of the linguoculturological type should be closer to encyclopedic ones than to explanatory 
dictionaries. The difference is that encyclopedic dictionaries contain only extralinguistic information, but linguoculturological ones focus their attention on a cultural connotation as an element of cultural significance" [3. P. 135].

The structural unit of the linguoculturological dictionary is a dictionary entry. It describes and explains the heading. However, the specificity of the lexicographic description is that in the entries of such dictionaries there is a culturological commentary that represent the interrelation between a particular linguistic unit and the culture of a particular society. This peculiarity is directed towards "objectification of the certain fragment of national world view connections and its structure" [3. P. 136].

It is necessary to emphasize, that a specificity of educational linguoculturological dictionaries of paremias is a remark, which is intended to correlate proverbs with the appropriate sphere of culture, as a special sign system: etymological commentary, information about region, culturological commentary. That is all aims to describe the connection between the figurative meaning of the paremia with different symbols and stereotypes of culture layers and codes. An educational dictionary is a lexicographic work of any type and volume, intended to help with learning language for direct communication [21. P. 123].

The description of most dictionaries is based on traditional approaches in the theory of language and lexicography, which were formulated during the compiling following dictionaries: "The Encyclopedic Dictionary of Linguistics" by V.N. Yartseva of 1990, "Experimental System Explanatory Dictionary of Stylistic Terms. Principles of Compilation and Selected Dictionary Articles" by S.Y. Nikitina and N.V. Vasilyeva of 1996, "Dictionary of Sociolinguistic Terms" by V.A. Kozhemyakin, N.G. Kolesnik and T.B. Kryuchkov, which has been release in 2006, other works of such kind. If we try to formulate the basic principles very briefly, then the most important thing in the compiling linguoculturological dictionaries is a necessity in using linguistic material as an object of description, implementation of the effective description principles, completeness and simple, concise presentation [11. P. 85].

The methodological base of the mentioned dictionaries does not fully help understand how exactly bilingual linguoculturological dictionaries are needed to be completed. The main question arises: how exactly this dictionary entry should describe the specificity of a certain language picture of the world, so that a foreign reader will be able to completely understand the main idea. The analysis of bilingual linguoculturological dictionaries will help identify the basic principles of their compilation.

Let's review the "Linguoculturological Dictionary of English Surnames" by S.V. Garagulya, released in 2018. This dictionary analyzes the history of the appearance and transformation of various proper names that have ever appeared on the territory of Great Britain and have stayed on people's minds. The entries contain the information about connection between local surnames and the cultural characteristics of the region and mentality, and follow the history of borrowing proper names from other languages. Dictionary entries are given in alphabetical 
order and cover over 150 culturally significant surnames [8]. What is also important to note, that this linguoculturological dictionary does not explore surnames from other regions but with similar meaning to English ones. In fact, it represents only one linguoculturological picture of the world.

The next dictionary mentioned is similar in some aspects to the previous one. Essentially, they have the same object of their entries. This is the "China. Names of all times. Well-known characters. Linguoculturological dictionary-reference book for Chinese language, culture, history and literature learners". compiled by N.N. Voropaev. The dictionary is mainly aimed at describing the names of the most famous historical and literary characters in China, and also represents and explains Chinese language fundamental idiomatics and colloquial metaphors, which associated with them. This dictionary has three sections: 1) National precedent characters of the Chinese-speaking cultural space; 2) The names of the most authoritative historical figures of China and the invariants of acceptance - epithets connected with them; 3) Precedent characters and comment by foreigners about them in the Chinese-speaking cultural space. The first and third sections are internally grouped only in the order of the Latin alphabet. The second one is divided into parts according to the type of activity of a particular person: politicians, military leaders, scientists, writers, famous merchants, masters of arts, philosophers and heroic figures [7]. Speaking about advantages of the dictionary, it is important to note that there is a whole section devoted to the quotations of people of different nationalities. That allows readers understand the linguoculturological picture of Chinese people and look at it from a different angle as a foreigner, which came to China for the first time.

Further on, let's analyze "Linguoculturological Dictionary of Geographical Names of Great Britain and the USA" compiled by S.I. Garagul. This work is a collection of the main culturally significant geographical names of Great Britain and the United States. Entries are arranged alphabetically. Certain geographic names take on the role of an object of dictionary description, its headings. The content of the entry usually gives a brief description of the specificities of the city, explains, if possible, the origin of the name, and provides with various Englishlanguage sources links, where this area was mentioned [9]. The disadvantage of this dictionary is an incompleteness of the internal systematization. The names of American and British geographic points are mixed that can brings some inconveniences during the use of the dictionary. The information is more of country studies rather than linguoculturological ones.

The "Names of animals in proverbs and sayings of the Russian and Indonesian languages: Linguoculturological dictionary" (2020); "Phytonyms in proverbs and sayings of the Russian and Indonesian languages: A Linguoculturological dictionary" (2021), edited by Ani Rahmat. In these dictionaries, the title unit of a dictionary entry is the name of an animal or plant is also of particular interest. In this dictionary, the heading unit of the dictionary entry is the name of the animal. The working classification of the material is based on the criterion of grouping the names of animals according to the differential system 'the degree of tameness of 
the animal by person'. Dictionary entries are structured as follows: the meaning (direct and figurative) and the etymology of the noun - the name of the animal, and if it has, the mythological component is also mentioned. Searching of constructing culturogical structure information is conducted at the entry of the dictionary of educational type: proverbs are divided depending on binomial conceptual units reflecting most frequent association of native speakers. Russian proverbs have translation into Indonesian, and translation from Indonesian into Russian is also given. At the end of the entry there are showed the cultural attitudes contained in the mentioned proverbs $[16 ; 17]$. Thus, the correlation of the paremia components with the culture codes is established, which the role of the paremia component plays in the concept of a sphere of a given linguistic community throughout symbols, stereotypes or standards.

As a disadvantage of this dictionary can be named the fact that Russian and Indonesian proverbs are considered separately, the authors do not set themselves the goal of making parallels between them and identifying the general and nationally specific in the cultural ideas of the two nations, leaving it to the mind of the reader.

Having studied the experience of constructing linguoculturological dictionaries of various types, as well as the principles of their compilation, we have developed the sample entry of an educational linguoculturological dictionary of paremias, united by the concept of DEAL (and microconcepts of work, labor, craft) with the background of their Chinese counterparts. The combination of the paremic material within one concept allows us demonstrate significant life guidelines developed by society, which are associated with value guidelines and are fixed in proverbs and sayings, playing the "role of prescriptions for life practices." [19. P. 18] The system of cultural attitudes "forms the basis of the core of culture." [19. P. 19]. The selection of cultural attitudes on the basis of paremic concepts allows us compare fragments of the national pictures of the world of two languages at the higher level.

During the description of proverbial material, a correlation of paremias with thematic groups of culture codes is established, the role of paremias in conceptosphere of culture is defined. Rethinking of different types of figurative bases of paremias within the thematic groups allows distinguish mental culture attitudes (as a certain level of generalization of cognitive meanings).

The cultural attitudes are an additional linguocultural description parameter for the paremias, phraseological units with the structure of a word collocation cannot express a complete thought on their own, in comparison, paremias usually have the structure of a complete sentence and represent a complete judgment of not only direct, but often of figurative meaning. Thus, the paremias: "Like father, like son", "As the tree, so the fruit", "A pig does not give birth to a beaver, and an owl does not hatch an eagle" can be combined with the idea that children take after their parents; from the dirty will not come out clean; bad will not make good. Symbols, stereotypes or standards make a background for emphasizing mental culture attitudes and correlation with culture codes. 
We offer the following dictionary entry of linguocultural learner's dictionary targeted at native Chinese speakers.

In accordance with the thematic principle of compiling the dictionary, it is suggested to use the following headings: BUSINESS, WORK, LABOR, HANDCRAFT, which are printed in bold Roman type. Under the thematic headings in the alphabetical order in bold straight timid type, have to be placed the names of the subheadings:

1) If work poorly that can lead to negative consequences;

2) Bad work is better than idleness or unfair labor;

3) No need to try to do someone else's work;

4) There are people who demand a reward regardless of what and how they did;

5) Sooner or later, but the work has to be done;

6) More work, less talk.

Under the headings of subheadings, there are dictionary entries, which also include several sections. The semantics of the paremia continue by giving its synonyms, and in the linguoculturological sense, these are units that have the same mental cultural settings as the heading unit. In contradistinction to other dictionaries, this section is not optional, because all units have one characteristic, express one mental setting of a culture. For example:

\section{Work}

No need to work too hard.

(Positive axiological assessment)

Horses can die because of work;

Working you cannot become rich, but easily can develop a slouch;

Workaholic will not live a long life;

The overzealous horse and the lazy one eat the same, but work differently;

Each person should do the work that he likes.

(Positive axiological assessment)

Everyone do the work they can do and earn their living;

Who cannot work properly, cannot rest;

If you like working can become a master;

Have to work with fun;

Working can earn for living.

(Positive axiological assessment)

Hardworking person can get everything, sluggard get nothing;

Working hard, eating good meal;

No work and the oven is cold;

Work hard, but it is nice to get paid;

Work more, talk less.

(Positive axiological assessment)

Listen, but do not quit your work;

Do not talk about how to finish the work, but do it;

Work with teeth, and laziness with the tongue [13]. 
The first section contains the proverb (s) - the heading (s), which is printed in light italics in lowercase letters: Work is not a wolf, it will not run away into the forest [13]. The lexical variants of the paremias (if there are any) are given in parentheses. Nearby to the heading there are functional and stylistic labels (book, common, playful, disapproving). They are printed in light italic, lowercase letters.

The second section contains information about the axiological value / antivalue of proverbial units: Positive axiological assessment / Negative axiological assessment. Positive one: If you like working can become a master; negative one: Working you cannot become rich, but easily can develop a slouch [13]. If it is possible to combine paremias into microgroups within the section of axiological assessment, have to add supplementary markers.

The third section is for semantization of paremic units. Here is given the descriptive interpretation of a proverb meaning (printed in Roman type without highlight). For example, the proverb "Working you cannot become rich, but easily can develop a slouch" can be taken as a warning for someone: you do not have to work too much, because there is always the chance to fail, will not get rich, but get sick.

In the fourth section, there is a cultural commentary. For this commentary, have to select the material that expresses an interesting, non-trivial point of view, draws an attention to the culture of the target language country.

\section{Cultural commentary}

In this case, the fragment of the literary text of the modern writer O.P. Yunyazova has been offered. Through the art, were shown the differences between the meanings of the concepts business and work.

Work is the realization of the creativity of the soul, it helps to fill the time, and therefore it helps fill the life. This is a game that contain setting tasks and solving them. Work is like a kitten or a foal. Born, lives, loves his master. Work is an integral and essential part of a creator. A company is only the result of that process. You can sell the company, but you cannot sell the business itself. The person who bought your company will start his business, and you will have to finish yours. Otherwise, you have to start some other, the one you at present are interested in [22. P. 264].

\section{WORK.}

Work is a cosmic energy, the very "electricity" that flows through a person. The sound " $b$ " means "to be". RaB (Russian word in the meaning of "slave") is the one who manifests Divine energy in being. Hence, the word "work" appear that means to create what God has not yet created, but continues to create with the hands of man.

People built beautiful palaces, planted gardens, forged plows, baked bread and did many other work that made their lives more beautiful, more pleasant, more human. Moreover, all this they did, of their own accord, but not because someone order them. Everyone chose for himself the work that seemed useful and exciting 
to him. With pleasure, the creator served the public good, and proudly called himself a servant of God.

About the word slave.

If a person obeys someone else's will, then he is a slave. A person who voluntarily does other people's tasks is a mercenary, volunteer, servant, and a person who, by his own will and because of his creative impulse, help to realize someone else's plan, is an assistant. Only a person, who of his own free will with creativity in his soul realize his own plan, can be considered as the Servant of God.

Happiness is when there is enough Ra energy. If you work for a creativity, and not only for a wealth, the process will definitely bring happiness [22. P. 234].

In the fifth section provides with illustrations (if they are):

1. Phenomenon of this attitude can be clearly seen in the countries of Eastern Europe that took place in the 15th-19th centuries during the period of secondary enslavement. In Russia, it is reflected in such proverbs as "Work is not a wolf, it will not run away into the forest", "Work loves fools" and, finally, in the fact that "slave" and "work" have the same root in Russian language. There are many examples of folk wisdom that show the attitude towards forced labor in Russian folklore, as in the folklore of other Eastern European peoples. Since the early 1930s, there has been a process of work ethic extinction that had been started in Russia even earlier in the 1860s-1920s [24].

2. This is because it fixes the attitude of different people to the same phenomena, actions, therefore, there are directly opposite judgments on the same occasion. For example: "Work is not a wolf, it will not run away into the forest", and next to it "Talk less, work more". You can continue by yourself the selection of such judgments of folk wisdom. Now let us turn to what common sense is [25].

3. Truthfully, in people's minds there was not pretty strong set of doctrines about the assignment "live for work": the proof is the proverb "Work is not a wolf, it won't run away into the forest" [26].

4. One thing need to say: farm laborer, sometimes say to him: that is enough, leave it, work is not a wolf, it will not run away into the forest [27].

5. In the sixth section, there are units that correlate in terms with the mental attitudes of culture in the Chinese language value. This description area is not constant, so, for example, for the setting WORK that allows you to gain respect in others in the Chinese language, there are a number of units: For example, “谁工作 的好, 谁就受尊敬”: “The best worker could have all honor”; “做活没技巧, 出 力不讨好”: “Hardworking, talented person is always respected by others, but a lazy one is always despised". The paremias of this section are typed in light italics. There are a number of units common in the meaning with following setting "Work more, talk less": “有本事的埋头苦干, 没能力的吹牛许愿”: “Good worker just work more, bad one only boast and promise”; “说千道万, 不如做事一件”: "Talk a lot, but do nothing” [23]. 
6. For a number of settings of the Russian language, there are no analogues in the Chinese language. They are lacunar in relation to the Chinese language. Therefore, for example, the following setting SHOULD NOT BE HURRY TO DONE WITH WORK, BECAUSE IT CAN ALWAYS BE FINISH LATER. In Russian is expressed by a number of units: Work is not devil - will not run away into the forest; Work is not a bear - you can view from the side; Work is not a wolf, it will not run away into the forest; The work is not devil, it will not go under the water.

This cultural setting has not been found in the Chinese language.

It is worth noting that some settings of the culture of the Chinese language do not have similar representations in the meaning in the Russian language. For example, “公事归公事, 友谊归友谊”: Despite the fact, we are friends, but at work we hold down our day job, follow strict rules of the company [23].

We can also mention this Chinese proverb “脸蛋漂亮不算好, 工作出色才 算好”: It does not matter if a person is handsome or not, the main thing is that he works well [23], in which it is noted that a person's ability to work well is much more valuable than his good appearance.

Thus, our proposed entry of the educational linguocultological dictionary includes the following elements: headings (business, work, labor, craft); sub-headings (mental attitudes of culture derived in the work); heading unit (s); section of axiological assessment; interpretation of the heading unit; mental attitude of culture; cultural commentary; linguistic and cultural commentary of individual words - components of paremia; illustrations; Chinese counterparts.

The definition of paremia contains a number of elements, necessary for the usage of this unit in written or spoken language. The image of this unit and its inner form point out speaker's emotive attitude towards the object of speech and reflect his/her attitude towards culture's moral and ethical norms which mean cultural connotations, typical for paremia.

\section{Conclusions and generalizations}

Illustrative zones reflect the features of paremia's functioning in modern speech. The examples from 1950s fiction rarely seen in modern Internet texts and NCRL (National Corpus of the Russian Language) point out that given unit probably goes into passive stock of language. Examples from newspapers, journalistic texts, articles published through Internet testify that given unit is widely used and demonstrate that tendency of speech democratization has grown.

The main feature of the educational linguistic and cultural dictionaries of paremia is cultural notes, which aim is to match paremia with the sphere of culture as the special system: etymological analysis, regional reference, cultural note aimed at the description of paremia's figurative content interaction through cultural norms, symbols, and stereotypes, with different cultural layers and codes. 


\section{References}

1. Vorobiev, V.V. (2008). Linguoculturology. Moscow: RUDN. (In Russ.).

2. Apresyan, Y.D. (1992). About the new dictionary of Russian language synonyms. The Bulletin of the Russian Academy of Sciences: Studies in Literature and Language, 1, 18-39. (In Russ.).

3. Bankova, T.B. \& Kalitkina, G.V. (2000). Lexicographic description of the ritual word. To the problem statement. In: Actual problems of Russian language studies: collection of articles, T.A. Demeshkina (Ed.). Tomsk. pp. 128-144. (In Russ.).

4. Berkov, V.P. (1975). Dictionary and people culture. Mastery of translation. Moscow: Sovetskij pisatel'. pp. 407-420. (In Russ.).

5. Aleshin, A.S. \& Zinovieva, E.I. (2020). Stable expressions of comparative structure: linguocognitive aspect (based on the material of the Russian and Swedish languages). RUDN Journal of Language Studies, Semiotics and Semantics, 11(1), 7-21. (In Russ.).

6. Vorobiev, V.V. \& Polyakova, G.M. (2012). Comparative linguoculturology as a new scientific direction. RUDN Journal of Informatization in Education, 7(3), 13-18. (In Russ.).

7. Voropaev, N.N. (2018). China. Names of all times. Well-known characters. Linguoculturological dictionary-reference book for Chinese language, culture, history and literature learners. Moscow: Zapadnaja kniga. (In Russ.).

8. Garagulya, S.I. (2018). Linguoculturological dictionary of English surnames. Moscow: URSS. (In Russ.).

9. Garagulya, S.I. (2019). Linguoculturological Dictionary of Geographical Names of Great Britain and the USA. Moscow: Infa-M. (In Russ.).

10. Demeshkina, T.A. (2011). Lexicographic direction in the Tomsk dialectological school. Tomsk State University Journal of Philology, 3(15), 31-37. (In Russ.).

11. Zinovyeva, E.I. (2010). Linguoculturography in the theory and practice of RFL. In: Russian language and literature in the modern humanitarian general educational space: materials of reports and messages of the international XV scientific and methodological conference. St. Petersburg: SPGUTD. pp. 126-133. (In Russ.).

12. Lukyanova, N.A. (2005). Typology of Russian linguistic dictionaries. Vestnik NSU. Series: History and Philology, 3(1), 43-44. (In Russ.).

13. Mokienko, V.M., Nikitina, T.G. \& Nikolaeva, E.K. (2010). A large dictionary of Russian proverbs. Moscow: OLMA. (In Russ.).

14. Nikitina, T.G. (2020). Structural and semantic modeling in the field of phraseology: forty years of experience and prospects. RUDN Journal of Language Studies, Semiotics and Semantics, 11(2), 175-197. (In Russ.).

15. Ozhegov, S.I. (1989). Dictionary of the Russian language: N.Y. Shvedova (Ed.). Moscow: Russian language. (In Russ.).

16. Rakhmat, A., Banit, S.V. \& Yakimenko, N.E. (2020). Names of animals in proverbs and sayings of the Russian and Indonesian languages: Linguoculturological dictionary. St. Petersburg: Unpad Press. (In Russ.).

17. Rakhmat, A., Banit, S.V. \& Yakimenko, N.E. (2021). Phytonyms in proverbs and sayings of the Russian and Indonesian languages: A linguoculturological dictionary. St. Petersburg: Unpad Press. (In Russ.).

18. Seliverstova, E.I. (2020). Levels of typological similarity in proverbs of various languages. RUDN Journal of Language Studies, Semiotics and Semantics, 11(2), 198-212. (In Russ.).

19. Telia, V.N. (1999). Priority tasks and methodological studies of the phraseological composition of the language in the context of culture. In: Phraseology in the context of culture. Moscow. pp. 13-25. (In Russ.).

20. Telia, V.N. (1996). Russian phraseology. Semantic, pragmatic and linguocultural aspects. Moscow: Languages of Russian culture. (In Russ.).

21. Educational lexicography, M.A. Shakhmatov (Ed.). (2011). St. Petersburg. (In Russ.).

22. Yunyazova, O.P. (2012). It's just a dream: [novel]. Moscow: Astrel. (In Russ.). 
23. Wen, Duanzheng. (2011). The Great Dictionary of Chinese Proverbs. Shanghai: Shanghai Dictionary Publ. House. (In Chinese.).

24. Gaidar, Yegor. (2006). The death of the empire. [Electronic resource] URL: https://clck.ru/ Tpr94 (accessed: 20.03.2021). (In Russ.).

25. Textbook on social studies. Profile level. 10th grade. (2007). [Electronic resource] URL: https://clck.ru/Tpr9N (accessed: 20.03.2021). (In Russ.).

26. Leontyeva, S. (2003). Labor childhood. "Home notes". [Electronic resource] URL: https://clck.ru/ TprBJ (accessed: 20.03.2021). (In Russ.).

27. Sheller-Mikhailov, A.K. (1900). Palace and monastery. [Electronic resource] URL: https://clck.ru/ Tps6z (accessed: 20.03.2021). (In Russ.).

\section{Библиографический список}

1. Воробьев В.В. Лингвокультурология. М.: РУДН, 2008.

2. Апресян Ю.Д. О новом словаре синонимов русского языка // Вестник Российской академии наук: Литературно-языковые исследования. 1992. 1. С. 18-39.

3. Банкова Т.Б., Калиткина Г.В. Лексикографическое описание ритуального слова. К постановке задачи // Актуальные проблемы изучения русского языка: сборник статей. Изобразительное искусство / под ред. Демешкина Т.А. Томск, 2000. С. $128-144$.

4. Берков В.П. Словарь и народная культура. Мастерство перевода. М.: Сов. Писатель, 1975. C. $407-420$.

5. Алешин А.С., Зиновьева Е.И. Устойчивые выражения сравнительной структуры: лингвокогнитивный аспект (на материале русского и шведского языков) // Вестник Российского университета дружбы народов. Серия: Теория языка. Семиотика. Семантика. 2020. Т. 11. № 1. C. 7-21.

6. Воробьев В.В., Полякова Г.М. Сравнительная лингвокультурология как новое научное направление // Вестник Российского университета дружбы народов. Серия: Серия: Информатизация образования. 2012. Т. 7. № 3. С. 13-18.

7. Воропаев Н.Н. Китай. Имена на все времена. Известные персонажи. Лингвокультурологический словарь-справочник для изучающих китайский язык, культуру, историю и литературу. М.: Западная книга, 2018.

8. Гарагуля С.И. Лингвокультурологический словарь английских фамилий. М.: УРСС, 2018.

9. Гарагуля С.И. Лингвокультурологический словарь географических названий Великобритании и США. М.: Инфа-М, 2019.

10. Демешкина T.A. Лексикографическое направление в Томской диалектологической школе // Вестник Томского государственного университета. Филология. 2011. Т. 3. № 15. C. $31-37$.

11. Зиновьева Е.И. Лингвокультурография в теории и практике РКИ // Русский язык и литература в современном гуманитарном общеобразовательном пространстве: материалы докладов и сообщений XV международной научно-методической конференции. СПб.: СПГУТД, 2010. С. 126-133.

12. Лукьянова Н.А. Типология русских лингвистических словарей // Вестник Новосибирского государственного университета. Серия: История и филология. 2005. Т. 3. № 1. C. $43-44$.

13. Мокиенко В.М., Никитина Т.Г., Николаева Е.К. Большой словарь русских пословиц. М.: ОЛМА, 2010.

14. Никитина Т.Г. Структурно-семантическое моделирование в области фразеологии: сорокалетний опыт и перспективы // Вестник Российского университета дружбы народов. Серия: Теория языка. Семиотика. Семантика. 2020. Т. 11. № 2. С. 175-197.

15. Ожегов С.И. Словарь русского языка: под. ред. Н.Ю. Шведовой. М.: Русский язык, 1989.

16. Рахмат А., Банит С.В., Якименко Н.Е. Названия животных в пословицах и поговорках русского и индонезийского языков: Лингвокультурологический словарь. Санкт-Петербург: Unpad Press, 2020. 
17. Рахмат А., Банит С.В., Якименко Н.Е. Фитонимы в пословицах и поговорках русского и индонезийского языков: Лингвокультурологический словарь. СПб.: Unpad Press, 2021.

18. Селиверстова Е.И. Уровни типологического сходства пословиц разных языков // Вестник Российского университета дружбы народов. Серия: Теория языка. Семиотика. Семантика. 2020. Т. 11 № 2. С. 198-212.

19. Телия В.Н. Приоритетные задачи и методологические исследования фразеологического состава языка в контексте культуры // Фразеология в контексте культуры. Сборник статей РАН. М.: Языки русской культуры, 1999. С. 13-25.

20. Телия В.H. Русская фразеология. Семантический, прагматический и лингвокультурный аспекты. М.: Языки русской культуры, 1996.

21. Учебная лексикография: под ред. М.А. Шахматова. СПб., 2011.

22. Юнязова О.П. Это просто мечта: [роман]. М.: Астрель, 2012.

23. Вэнь Дуаньчжэн. Большой словарь китайских пословиц. Шанхай: Shanghai Dictionary Publ. House, 2011.

24. Гайдар Е. Гибель империи. 2006. [Электронный ресурc] URL: https://clck.ru/Tpr94 (дата обращения: 20.03.2021).

25. Учебник по обществознанию. Уровень профиля. 10-й класс. 2007. [Электронный ресурс]. Режим доступа: https://clck.ru/Tpr9N (дата обращения: 20.03.2021).

26. Леонтьева С. Трудовое детство. «Домашние заметки». 2003. [Электронный ресурс]. Режим доступа: https://clck.ru/TprBJ (дата обращения: 20.03.2021).

27. Шеллер-Михайлов А.К. Дворец и монастырь. 1900. [Электронный ресурс]. Режим доступа: https://clck.ru/Tps6z (дата обращения: 20.03.2021).

\section{Information about the authors:}

Yakimenko Nadezhda Yegorovna, PhD of Pedagogical Sciences, Associate-Professor, AssociateProfessor of the Department of Russian as a Foreign Language and Methods of Its Teaching Faculty of Philology of the Federal State Budgetary Educational Institution of Higher Education "St. Petersburg State University"; research interests: phraseology and paremiology of the Russian language, aphoristics of the Russian language, phraseography; e-mail: yak.nadega@mail.ru ORCID: 0000-0002-4191-6774 SPIN-code: 5376-8660

Qiu Xueying, Post-graduate Student, the Department of Russian as a Foreign Language and Methods of its Teaching, "St. Petersburg State University"; research interests: phraseology and paremiology of the Russian language, e-mail: cyuein.tziu@yandex.ru

\section{Информация об авторах:}

Якименко Надежда Егоровна, кандидат педагогических наук, доцент, доцент кафедры русского языка как иностранного и методики его преподавания филологического факультета Санкт-Петербургского государственного университета; научные интересы: фразеология и паремиология русского языка, афористика русского языка, фразеография; e-mail: yak.nadega@mail.ru ORCID: 0000-0002-4191-6774 eLIBRARY: 5376-8660

Цю Сюеин, аспирант кафедры русского языка как иностранного и методики его преподавания Санкт-Петербургского государственного университета; научные интересы: фразеология и паремиология русского языка, e-mail: cyuein.tziu@yandex.ru 